Универзитет у Београду, Историја и филозофија природних наука и технологије, Београд

DOI 10.5937/kultura1963137S

УДК 330.341 .1

316.42

стручни рад

\title{
ПУТЕВИ TEXНOЛOГИJA
}

\section{НАЦИОНАЛНА УЛАГАЊА У КОНТЕКСТУ ГЛОБАЛНОГ РАЗВОЈА ТЕХНОЛОГИЈА}

\begin{abstract}
Сажетак: Конвенционална економска теорија тврди да су технологија и технолошки развој од иентралне важности за економски раст, а економски раст је од иентралне важности за капитализам и институције које су створене на овој идеологији. У овом раду преиспитаће се важност улагања у технологије, како за национални, тако и за глобални економски раст пре свега полазећи од тезе да технолошке иновације зависе од институција система слободног тржитта. Раст националне економије такође зависи од стопе запослености, па се кроз рад провлачи и мисао да ће технолошки напредак девалвирати људски рад независно од степена образовања. Технолошке иновације такође уносе бригу јер доносе промене у оквиру актуелног друштвено- привредног система.
\end{abstract}

Кључне речи: технологија, иноващије, економски раст, индустријска револуција, неолудизам

\section{Економска стагначија и нове технологије}

Економије западних земаља се последњих година суочавају са стагнацијом, што значи да је привредни раст спор и веома низак, а незапосленост способне и образоване радне снаге висока. Примећује се да технолошке иновације данас (насупрот онима из средине прошлог века) не само да не повећавају производњу, већ доводе и до непожељног хонорарног радног времена. Глобализација, технолошки развој, образовање и фискална политика су теме које политичка економија покушава да реши. Глобализација и нове технологије пребацују радну снагу у иностранство на јефтинија тржишта или аутоматизују радна места. То са једне стране утиче на 
смањење потребе за националном радном снагом, а са друге стране повећава економске неједнакости како на локалном, тако и на глобалном нивоу. На неједнакости у расподели богатства такође утиче фискална политика која смањује порезе богатима, а државни систем недовољно улаже у бесплатно образовање. Дугови и презадуживања земаља на које су утицале финансијске институције које такође постају презадужене и превелике да би пропале (Too Big to Fail) ${ }^{1}$ указују на то да се мора мењати и фискална политика држава.

Западни финансијски модел економије који комбинује институционалне иновације као продукт финансијског посредовања (банке, берзе, осигурање, тржиште обвезница) по мишљењу Најла Фергусона (Nail Ferguson) на дужи рок пролазио је боље за разлику од централног планирања и самим тим је и тежио да се прошири по свету, прво у облику империјализма, а затим глобализације. ${ }^{2}$ Дарон Асемоглу (Daron Acemoglu), а затим и Фергсуон мишљења су да технолошки развој, као и сама потрага за иновацијама зависе од институција, односно од модела људског организовања. Људима су институције оно што су пчелама кошнице. ${ }^{3}$ Људи се по том принципу организују по одређеним правилима, унутар одређених зидина и одређене структуре. У оквиру политичког система кошница је успостављена хијерахијски, док у економској сфери постоји више слобода. Постоје два модела институционалног организовања: ограничени (спор економски раст, централизована влада, друштвени односи дефинисани по хијерархији и по династијским линијама) и отворени (бржи економски раст, грађанско друштво са мноштвом организација, децентрализована влада, подстицаји државе за стварањем елитистичких и других организација).

„Владавина права за елите била је један од три улазна основа који претходе транзицији у систем отвореног приступа, а друга два су била рађање вечито живих организација у приватној и јавној сфери, и консолидована контрола војске."

1 Too big to fail (превелико за неуспех) је колоквијални исказ који се односи на теорију засновану на тврдњи да су одређене корпорације, посебно финансијске институције, толико велике и тако међусобно повезане да би њихов неуспех био катастрофалан за већи економски систем, те да их стога мора подржати влада када се суоче са потенцијалним неуспехом.

2 Ferguson, N. (2010) Uspon novca, Beograd: Plato, str. 342.

3 1714. године је објављена књига Бернарда Мандевила „Басна о пчелама" о којој говори Најл Фергусон у: Ferguson, N. (2016) Velika degeneracija, Kako se institucije raspadaju i ekonomije umiru, Beograd: Plato, str. 16.

4 Исто, стр. 28. 
Институције и државе такође могу бити инклузивне и екстрактивне (извлачење средстава већине у корист мањине). У смислу владавине права инклузивне институције подстицале су економски раст. Зашто одређене државе пропадају, Асемоглу и Џејмс А. Робинсон (James A. Robinson) објашњавају у својој књизи Зашто народи пропадају: Порекло моћи, nросперитета и сиромаштва (Why Nations Fail: The Origins of Power, Prosperity, and Poverty) где кажу да је то управо због постојања екстрактивних институција наводећи пример Колумбије, али и Аргентине под колонијалним утицајем Шпаније, а да су се земље кроз инклузивне иниституције и добар однос са развијеним земљама много брже развијале као што је то био случај са Сингапуром као британском колонијом.

Глобализација и нове технологије неминовно утичу на све земље, и оне сиромашне и оне богате, с тим што се традиционално сматра да технолошке иновације подстичу економски раст било које земље. Са друге стране, разумљив је страх опонената технолошких иновација да ће нас машине заменити, јер се то већ дешава под утицајем информационих технологија и технологија вештачке интелигенције. Смањује се цена људског рада и деловања што је такође један од узрока економске стагнације. Филозофија технологије познаје научнике који су сумњали у валидност технолошког прогреса, а то су Алберт Боргман (Albert Borgmann), Дон Ајди (Don Ihde), и Хјуберт Драјфус (Hubert Dreyfus).

„Научни лудизам не признаје своје постојање”, указује чувени Дејвид Едгертон (David Edgerton), али технолошки је и те како присутан и то у оквирима саме науке. Научна заједница у оквиру својих хуманистичких центара (нпр. Институт за будућност човечанства при Оксфордском универзитету - Future of Humanity Institute, University of Oxford) проучава етику и морал нових технологија као и досеге вештачке интелигенције.

\section{Технолошки развој кроз глобалне технолошке иноваиије}

У овом раду осврнућу се на три основне идеје које у основи имају привредни развој, подстакнут улагањем у технологиje: (1) да је технолошки развој уследио стимулацијом институција и обликовањем националних институција (Дарон Асемоглу и Џејмс А. Робинсон) и (2) да националне институције у ствари нису имале битну улогу, макар не до средине

5 Edgerton, D. (03 March 2011) In praise of Luddism, Nature, Vol 471, Macmillan Publishers Limited, p. 28. 
18. века (Џоел Мокир - Joel Mokyr), или пак (3) да национално улагање у технологије није битно, јер је технолошки развој увек био глобалан (Дејвид Едгертон - David Edgerton). ${ }^{6}$ Сходно томе поставља се питање да ли технолошке иновације треба да буду националног карактера или пак глобалне на шта у основи указују ове основне идеје.

Асемоглу сматра да су технолошки и економски раст држава у великој мери последица одређених друштвених закона и норми, и наравно институција. Институционално деловање је у оквиру четири сфере: демократије, капитализма, владавине права и грађанског друштва. Слично овој тези, често цитиран Франсис Фукујама (Francis Fukuyama) у делима Најла Фергусона који такође афирмише теорију институuија, дефинише „три компоненте савременог политичког уређења“, а то су јака и способна држава, подређивање државе владавини права и одговорност власти пред свим грађанима. ${ }^{7}$

Француска револуција и теорија слободе је била успешна у теорији, а неуспешна у пракси како тврди Фергусон ${ }^{8}$. Француска је дала предност једнакостима, а САД слободи. Такво опредељење довело је до централистичког уређења државе у Француској које повлачи слабије грађанско друшто и спорији економски раст. Тај модел извезен је и у афричке и азијске земље/колоније где су резултати били још лошији. Једна од главних теза у корист институција има темељ у владавини права, те Фергусон наводи да је правна заштита инвеститора главни прогнозер финансијског развоја, имајући у виду пре свега енглеско право и развијене отворене институције у Британији у 18 . веку, а са друге стране указујући и на кинески правни систем/оквир који није довољно добар за инвеститоре. ${ }^{9}$

Насупрот идеји да су само државне институције предуслов технолошког развоја, Мокир у својим радовима указује на развој научних изума и технологија и без постојања

6 Дарон Асемоглу је на трећем месту, иза Пол Кругмана (Paul Krugman) и Грег Манкјуа (Greg Mankiw), на листи „Омиљени економисти испод 60 година старости”, анкети рађеној међу америчким економистима 2011; а према IDEAS/RePEc, од августа 2017. године, он је најцитиранији економиста у последњих 10 година. Са друге стране, Едгертон, као један од водећих историчара у Великој Британији, у последњих 20 година објављује многобројне радове који се супротстављају и изазивају конвенционалне анализе науке и технологије.

7 Ferguson, N. (2016) Velika degeneracija, Kako se institucije raspadaju i ekonomije umiru, Beograd: Plato, str. 28.

8 Исто, стр. 81.

9 Исто. 


\section{ЈЕЛЕНА СТАНУЛОВИЋ}

националних институција, као и да знање није имало граница међу научницима. Нације су тек добијале на значају по националности научника, проналазача, иноватора и то у форми институције, то јест заједнице изван државних граница. Заједница о којој је реч била је позната као Respublica literaria (Република писама - Republic of Letters) и деловала је крајем 17. и 18. века у Европи и Америци. То је била група међународно повезаних научника и интелектуалаца, заправо елитна група интелектуалаца и научника који су проверавали своја нова знања кроз писма и састанке. „Грађани” ове Републике били су у моралној обавези да одговоре на писма. Са друге стране, Република се понашала као институција јер је подржавала функционисање тржишта и идентитет. ${ }^{10}$, 'Република писама" је била транснационална институција, где националност, религија и социјално порекло научника није било релевантно за процену његовог или њеног научног доприноса, а састојала се од мреже људи који се можда никад нису упознали, али деловали су као јавна наука која се на крају могла трансформисати у технолошки напредак и економски развој. Ипак, већ почетком 18. века рађају се мотиви за личну добит увођењем награда и „патентизацијом” изума, тако да се питање тачне улоге науке у индустријској револуцији и даље расправља. Нема сумње, међутим, да је убрзаним растом привреде порастао и допринос науке, која постаје доминантна мотивациона моћ у периоду након 1830. године.

Јака академска струја са једне стране подстиче развој демократских неолибералних институција које су представљене као покретачи економског развоја, јер „демократски системи лакше доводе до стицања богатства"11 за разлику од средњевековне тираније, иако и даље постоје друштва која су имала невероватно брз економски раст иако нису биле демократије (Сингапур, Кина, Јужна Кореја). Са друге стране, из Енглеске, мајке тачеризма и неолиберализма, долази Едгертон као симпатизер лудиста ${ }^{12}$ и тумачи да је технолошка

10 Mokyr, J. (2016) Institutions and the Origins of the Great Enrichment, Atlantic Economic Journal 44, No. 2, Published online 30 May 2016: International Atlantic Economic Society, p. 252.

11 Фергусон, Н. (2012) Моћ новиа, Београд: Службени гласник, стр. 393.

12 Лудисти су припадници покрета радника који су у Енглеској, 1811. године разбили машине које је требало да их замене у ткању вуне. Име су добили по раднику Неду Луду који је први поломио свој разбој. Од тада, сматра се да је лудиста неко ко се противи напретку, посебно науци и технологији. Данас се неолудисти не противе општем технолошком прогресу, већ су против одређених појава које настају услед утицаја нових технологија и у одређеном контексту критикују технолошки прогрес што заправо ради и научна заједница. 
иновација глобални производ и да национални системи нема потребе да полажу наде у сопствени привредни раст кроз улагање у технолошко развојне програме. Он у својој књизи Шок старога - технологија и глобална историја од 1900. до данас (The schock of the Old. Technology and global history since 1900) сугерише да максимална употреба технологије, па самим тим и утицаји технолошких иновација често бивају постигнути неколико деценија после њеног открића.

Наука и развој технологија су глобални феномен, те лекови који нам се прописују, машине (попут рачунара) или интернет мреже нису производ истраживања и развоја само једне земље. Ако сагледамо размишљања Едгертона, критичара конвенционалне економије и историје технологија, институционални оквир који поспешује технолошке иновације и улагање у истраживање и развој једној држави можда и није потребан све док је у могућности да увози иновације. Едгертон говори о томе да је за већину земаља увоз нових технологија био важнији од њиховог националног развоја, али и да постоји моћан утицај, свуда у свету, да верујемо да националне политике треба усмерити на привредни развој стимулисан развојем технологија. Тај технолошки развој је поврх свега усмерен на обично три области, а то су: нанотехнологија, информационе технологије и биотехнологије. ${ }^{13}$ Тако Европска унија предлаже да 3\% бруто друштвеног производа одлази на истраживање и развој, а овај постотак је смерница за повећање стопе раста националних економија. Едгертон тумачи да национално улагање у истраживање и развој може бити добро за светску економију, али не нужно за земљу која улаже. Наравно да националне политике у домену истраживања и развоја, ако нису усмерене, могу бити лоше за опште добро, као и за глобалну економију. Када се спомене увоз нових технологија, одмах се помисли на Кину. Међутим, чињеница је да већина земаља добија нову технологију из иностранства, а увоз технологија односи се и на западне економије као што су Уједињено Краљевство и Француска. Тако Француска, на пример, наводи да је прва на свету по производњи нуклеарне електричне енергије, а сама технологија је развијена у Сједињеним Америчким Државама.

\section{Питање привредног раста}

Пратећи ток технолошког раста кроз индустријску револуцију видећемо како се историјски технологија ширила

13 Edgerton, D. (23 October 2008) The charge of technology, Nature, Vol 455, Macmillan Publishers Limited, p. 1031. 
и утицала на светски привредни раст, а не нужно на раст националних економија које су творци технологија.

Британска индустријска револуција се веома брзо проширила широм Европе. Велики иноватори у великој мери нису били у могућности заштитити оно што би се сада назвале њихова права интелектуалне својине. Такође, изузетном брзином, нова технологија је копирана и репродукована на континенту и преко Атлантика. Индустрија памука је била прва механизована текстилна индсутрија. Прво памучно вретено изграђено је 1771. године у Британији, да би се касније проналаском Ватове парне машине изградиле прве фабрике. Требало је седам година да се у Француској појави копија памучног вретена, а убрзо потом и копија Ватове парне машине. Прву фабрику парних машина на свету Ват je основао 1782. године близу Бирмингема. Године 1784. захваљујући индустријској шпијунажи, долази се и до немачке верзије и памучног млина и парне машине. Американци, који су имали могућност да производе свој памук, као и да користе руднике сопственог угља, били су мало спорији: први памучни млин појавио се 1788 . године, а први парни мотор 1803. године. Технолошке иновације потом копирају и преузимају Немци, па Белгијанци, Холанђани и Швајцарци. Како се ефикасност технологије побољшавала, а економска продуктивност повећавала, па и тамо где је рад био јефтинији и где је било несташице угља, земље су се индустријализовале. Између 1820. и 1913. године број вретена на свету повећао се четири пута брже од светске популације, а стопа повећања била је двоструко бржа у иностранству него у Уједињеном Краљевству. Таква су била и повећања продуктивности, а расла је и тражња. Као резултат тога, између 1820. и 1870 . године велики број северозападних европских и северноамеричких земаља постигле су британске стопе привредног раста; а бржи привредни раст у односу на Велику Британију забележиле су Белгија и Сједињене Државе, а потом и Немачка и Јапан. Источноевропске земље индустријализовале су се крајем и почетком 20. века, а Кина и Индија тек средином 20. века. ${ }^{14}$

Другу половину 20. века обележила је технолошка иновација звана интернет, роботика и чињеница да ће машине заменити физички рад људи. Ова технолошка револуција добија снагу научне револуције јер се мења економски и друштвени систем света, људи се другачије понашају, економски

14 Погледати бруто друштвени производ по глави становника на адреси: www.ourworldindata.org где је могуће бирати државе од интересовања; https://ourworldindata.org/grapher/real-gdp-per-capita-PennWT?country $=\mathrm{USA}+\mathrm{BEL}+\mathrm{FRA}+\mathrm{HRV}+\mathrm{DEU}+\mathrm{IND}+\mathrm{SGP}+\mathrm{SRB}+\mathrm{JPN}+\mathrm{GBR}+\mathrm{CHN}$ 
модели прелазе са производње и повећања продуктивности на модерни економски модел услуга. Да ли и интернет, као нова технолошка револуција у овом случају иде на уштрб капитализму и да ли то значи да привредни раст у ствари није могућ јер нема производње, а самим тим ни повећања продуктивности (који је обично условљен технолошким развојем)?

Прослављени Нобеловац из области економије, Роберт Солоу (Robert Solow) поставља питање будућег економског ра-

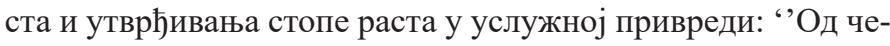
га зависи укупно побољшање факторске продуктивности у услужној привреди и шта би то било: повећање радне снаге, повећање квалификованог рада, или шта?" 15 Солоу такође проучава иницијални капитал улагања и поврат на инвестицију (Return on Investment - ROI - РОИ), а с обзиром да се у економији услуга капитал своди на друштвени и интелектуални, данашња економија нажалост нема тачан одговор како израчунати РОИ. Проблем лежи у томе јер улагање у друштвени, т.j. људски капитал подразумева неколицину улазних фактора као што су приватна и национална улагања, улагања трећих лица, тацитно знање, итд. ${ }^{16}$

Ако економија постаје услужна, да ли се глобални производ као што је то интернет или неки њен дериват (игрица, апликација, портал, друштвена мрежа) може сматрати националним технолошким производом утолико пре ако је држава уложила у друштвени и интелектуални капитал који су заслужни за развој иновације, или пак директном инвестицијом у истраживање и развој? На ову тему указује и Едгертон као што је раније објашњено.

\section{Технолошка анксиозност}

Навели смо претходно да постоји донекле оправдана брига узрокована технолошким иновацијама. Технолошко узнемирење (Technological Anxiety) може имати неколико облика, али три су основне забринутости: прве две „бриге” су засноване на „оптимистичном” ставу да ће технолошке иновације наставити да расту, можда и убрзано, а трећа „брига”

15 Solow, R. (2009) Does Growth Have a Future? Are These Questions Related?, History of Political Economy 41 (annual suppl.) Durham: Duke University Press, p. 4.

16 Интересантно је да је српски дипломата, економиста и математичар, Коста Стојановић у свом делу „Основи теорије економски вредности” почетком 20. века, уводећи ентропију техничких наука у економију, математичком аналогијом показао да су национална улагања у људски, интелектуални и друштвени, а пре свега морални капитал заслужни за привредно и друштвено благостање. 


\section{ЈЕЛЕНА СТАНУЛОВИЋ}

је да заправо неће бити довољно технолошког напретка за будући привредни раст. ${ }^{17}$ Једна од најчешћих забринутости је да ће технолошки напредак заменити људски рад машинама, што би могло довести до технолошке незапослености и даље повећање неједнакости у кратком року, чак и ако су дугорочни ефекти корисни. Друга брига тиче се морала и импликације технолошког процеса за људску добробит. У случају индустријске револуције, брига се односила на дехуманизирајуће ефекте рада, а нарочито на рутинизовану природу фабричког рада. ${ }^{18}$ Трећа „брига”, проузрокована стагнацијом економског раста, доводи у питање даље технолошке иновације постављајући питање да ли су оне у тој мери могуће.

Технолошки напредак је до сада био у облику иновације производа, те је тако створио потпуно нове секторе за економију, а самим тим и потпуно нову категорију радних места као што су лични модни консултанти, стручњаци за сајбер сигурност, менаџери за онлајн репутацију и многе друге нове професије. Тако прва „брига” из индустријске ере није била основана. Са друге стране, Мекинси глобални институт (McKinsey Global Institute) је објавио извештај о дванаест главних нових технологија за које сматра да ће узбуркати постојеће тржишне и друштвене постулате. ${ }^{19}$ То су: (1) мобилни интернет, (2) аутоматизација знанственог рада (аутоматизација високо-образованих занимања као што су фармацеути, правници, преводиоци, архитекте, и сл.), (3) интернет ствари (Internet of Things), (4) облак (Cloud) технологија, (5) напредна роботика, (6) аутономна возила, (7) складиштење енергије, (8) геномика следеће генерације, (9) ЗД штампање, (10) напредни материјали, (11) напредна испитивања на пољу експлоатације нафте и гаса, (12) обновљива енергија. У извештају се сугерише да ће неке од жртава бити радници који се тренутно сматрају високо квалификованим и који су уложили пуно времена и новца у стицању знања и вештина тако што ће доћи до „аутоматизације знанственог рада" уз помоћ софтвера који ће радити управо оне ствари за које су се људи школовали. Страхује се да би вештачка интелигенција (Artificial Intelligence - AI) ускоро могла да замени правнике, банкаре и слична занимања, док

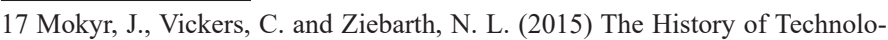
gical Anxiety and the Future of Economic Growth: Is This Time Different? Journal of Economic Perspectives-Volume 29, Number 3, pp. 31-50.

18 Исто, стр. 31-50.

19 Manyika, J., Chui, M., Bughin, J., Dobbs, R., Bisson, P. and Marrs, A. (May 2013) Disruptive technologies: Advances that will transform life, business, and the global economy, New York: McKinsey Global Institute. 
би напредна роботика могла даље да доведе до смањења запослености у производњи, али би могла заменити и здравствене раднике, грађевинске раднике, итд. Тако на пример, у Јапану већ постоје хуманоидни роботи који се користе као помоћ постојећим здравственим радницима. Већи роботи физички преносе пацијенте ако је то потребно, а мањи, интерактивни роботи помажу у спречавању самоће када су у питању старији пацијенти. Утицајни амерички економиста Пол Кругман (Paul Krugman) који је уверења да ће образовање на неки начин решити проблем уништавања радних места технологијом, је у Њујорк Тајмсу (The New York Times) написао колумну као неолудиста јер је указао да је данас много мрачнија слика утицаја технологије на рад „где ће високо образовани радници као и мање образовани радници девалвирати и изгубити посао, а подстицаји за вишим образовањем могу да створе више проблема, него што их решавају." 20

\section{Закључак}

Промене што се збивају у соиијалним срединама, везане су за човека, друштво и његову околину физичку. Друштво ствара ту околину и мењ а се под њеним утицајем. ${ }^{21}$

Коста Стојановић

У друштвено-економским системима свака промена у виду научно-технолошког прогреса мења понашања људи и машина. Економија је пре свега социјално оријентисана и треба да буде друштвено одговорна, а то значи да треба да буде постављена тако да служи људима у контексту моралних и етичких начела.

С једне стране, Фукујама тврди да „у сфери политике и економије изгледа да је историја прогресивна и дирекциона, а на крају 20. века кулминирала је у либералној демократији као јединој разумној алтернативи за технолошки напредна друштва““22. Са друге стране неспорно је да се глобализацијом губи национални идентитет али и да светски економски прогрес зависи од улагања националних економија у истраживање и развој. Светски економски прогрес је прогрес технолошки напредних друштава у ком су институције подређене систему слободног отвореног тржишта, а то значи да

20 Krugman, P. (14 June 2013) Sympathy for the Luddites, The New York Times, 14 June 2013, p. A27.

21 Стојановић, К. (1910) Основи теорије економских вредности, Београд: Српска краљевска академија, стр. 5.

22 Фергусон, Н. (2012) Моћ новца, Београд: Службени гласник, стр. 393. 
ће економска неједнакост и даље расти (богата друштва ће постати богатија, а сиромашна сиромашнија).

Данашњи економисти као што је Тома Пикети (Thomas Picketty) тврде да се успех једне економије може проценити пратећи животни стандард грађана током дужег периода, и то пре свега пратећи раст неједнакости. Економска неједнакост је увек била присутна, али такође и увек различита током историје што показују економска истраживања данашњице, па тако Тома Пикети у свом ,'Капиталу“ (Capital in the Twenty - First Century) указује да је неједнакост до Првог светског рата била висока, да би у послератним годинама до 1970. неједнакост у расподели доходака и богатства била драстично смањена, делимично ратовима и ,'Великом депресијом“, а делимично и деловањем кејнзијанског система који подразумева државне ингеренције. ${ }^{23} 1980$-их на светску сцену ступа неолиберализам предвођен саксонском струјом тачеризма где је реформом и приватизацијом јавног сектора кроз дерегулацију привреде поново дошло до великих неједнакости. Ово нас наводи на размишљање да технолошке иновације, поготово оне револуционарне, које су имале улогу у промени понашања и машина и људи (нпр. интернет) подстичу економске неједнакости.

Механичке иновације индустријске револуције деловале су као замена за људску снагу и спретност, али машина тог времена није могла да разуме, упоређује, рачуна, чита, чује, па чак и доноси одлуке. Данас, ако вештачка интелигенција и роботика наставе садашњи тренд развоја, будуће машине ће бити у стању да спроведу скоро све људске капацитете, наравно у одређеном контексту и у одређеној мери, те ће и стварно заменити људски рад који сада познајемо. Чини се да ће овога пута то бити страшније, али узмимо у обзир да се у 19. и 20. веку нису могли замислити послови који сада постоје. Научници су, са друге стране, имали кључну улогу када је било потребно да се опонира одређеним технолошким иновацијама па су се супротставили такозваној геџет (gadget - технолошка справица) манији током Другог светског рата, па и након тога. Наиме, енглеска влада је захтевала од тадашњих научника да предложе нове идеје како би се унапредило или створило ново оружје, али је научна заједница то одбила. Стога, закључујемо да ће научници и даље имати кључну улогу у развоју нових технологија.

Неолудизам се полако враћа на сцену, додуше још увек вири иза завесе која се још није подигла. Заправо, противљење

23 Piketty, T. (2014) Capital in the Twenty - First Century, Cambridge: The Belknap Press of Harvard University Press. 


\section{ЈЕЛЕНА СТАНУЛОВИЋ}

већини нових идеја, проналазака и иновација јесте суштинско за напредак, како примећује Едгертон. На крају, ако је идеја заиста супериорна, она ће се бити прихваћена, само треба водити рачуна да то не буде са великим кашњењем, и да то нема штетне последице за интелектуални и политичко -друштвени развој. Развој нових технологија предмет су изучавања многих хуманистичких наука које испитују морал и етички дизајн технологија, те је системско размишљање у контексту стварања нових технологија и њихових имплементација кључно. Пример тога су свакако и национална улагања у контексту њиховог глобалног развоја и ширења.

\section{ЛИТЕРАТУРА:}

Acemoglu, D. and Robinson, J. (2012) Why Nations Fail: The Origins of Power, Prosperity, and Poverty, New York: Crown.

Bertucci, P. (October 2013) Enlightened secrets: silk, intelligent travel, and industrial espionage in eighteenth- century France, Technology and Culture, Volume 54, Number 4, Baltimore: The Johns Hopkins University Press, pp. 820-852.

Borstrom, N. and Cirkovic, M. (2008) Global Catastrophic Risks, Oxford: Oxford University Press, pp. 91-119.

Buttonwood's notebook (10 March 2014) Back to the 19th century Does slow growth lead to greater inequality?, The Economists, 20 June 2019, https://www.economist.com/blogs/buttonwood/2014/03/demography-and-inequality

Edgerton, D. (23 October 2008) The charge of technology, Nature, Volume 455, London: Macmillan Publishers Limited.

Edgerton, D. (03 March 2011) In praise of Luddism, Nature, Volume 471, London: Macmillan Publishers Limited.

Edgerton, D. (2008) The schock of the Old. Technology and global history since 1900, London: Profile Books Ltd.

Edgerton, D. (2005) Science and the nation: towards new histories of twentieth-century Britain, Historical Research, Volume 78, Issue 199, London: Institute for Historical Research, pp. 96-112.

Krugman, P. (14 June 2013) Sympathy for the Luddites, The New York Times, 14 June 2013, p.A27, 20 June 2019, http://www.nytimes.com/2013/06/14/opinion/krugman-sympathy-for-the-luddites. html?mcubz=1

Krugman, P. (2012) Okončajte ovu depresiju. Odmah!, Smederevo: New Press.

Leković, V. (2015) Determinantne ekonomske (ne) jednakosti i njene implikacije za održivi ekonomski razvoj, Ekonomski horizonti, Kragujevac: Ekonomski Fakultet Univerziteta u Kragujevcu. 


\section{ЈЕЛЕНА СТАНУЛОВИЋ}

Manyika, J., Chui, M., Bughin, J., Dobbs, R., Bisson, P. and Marrs, A. (May 2013) Disruptive technologies Advances that will transform life, business, and the global economy, New York: McKinsey Global Institute, 20 June 2019, http://www.mckinsey.com/business-functions/ digital-mckinsey/our-insights/disruptive-technologies

Mokyr, J. (2016) Institutions and the Origins of the Great Enrichment, Atlantic Economic Journal 44, No. 2, Published online 30 May 2016: International Atlantic Economic Society.

Mokyr, J., Vickers, C. and Ziebarth, N. L. (2015) The History of Technological Anxiety and the Future of Economic Growth: Is This Time Different? Journal of Economic Perspectives, Volume 29, Number 3 , pp. 31-50.

Piketty, T. (2014) Capital in the Twenty - First Century, Cambridge: The Belknap Press of Harvard University Press.

Piketty, T. (2015) The Economics of Inequality, Cambridge: The Belknap Press of Harvard University Press.

Rosenberg, N. and Birdzell, L. E. (1986) How the West Grew Rich, New York: Basic Books.

Solow, R. (2009) Does Growth Have a Future? Are These Questions Related?, History of Political Economy 41 (annual suppl.), Durham: Duke University Press.

Стојановић, К. (1910) Основи теорије економских вредности, Београд: Српска краљевска академија.

Ferguson, N. (2016) Velika degeneracija, Kako se institucije raspadaju i ekonomije umiru, Beograd: Plato.

Фергусон, Н. (2012) Моћ новц̧а, Београд: Службени гласник.

Ferguson, N. (2010) Uspon novca, Beograd: Plato.

http://www.ourworldindata.org 


\title{
ЈЕЛЕНА СТАНУЛОВИЋ
}

Jelena Stanulović

University in Belgrade, History and Philosophy of Natural Sciencies and Technology, Belgrade

\section{TECHNOLOGY PATHWAYS}

\section{NATIONAL INVESTMENTS IN THE GLOBAL TECHNOLOGY GROWTH CONTEXT}

\begin{abstract}
Conventional theory of economy claims that technology and technological development are key factors to economic growth, while economic growth is central to capitalism and institutions created on this ideology. In this paper, the importance of technological investments will be re-examined for both national and global economic growth, having in mind the notion that technological innovations depend on the institutions of the free market system. The growth of the national economy also depends on the employment rate. Therefore, the idea that technological progress might devalue human labour regardless of the level of education will also be discussed in this paper. Since technological innovations bring changes within the actual socioeconomic system, they also bring anxiety.
\end{abstract}

Key words: technology, innovations, economic growth, industrial revolution, neoludism

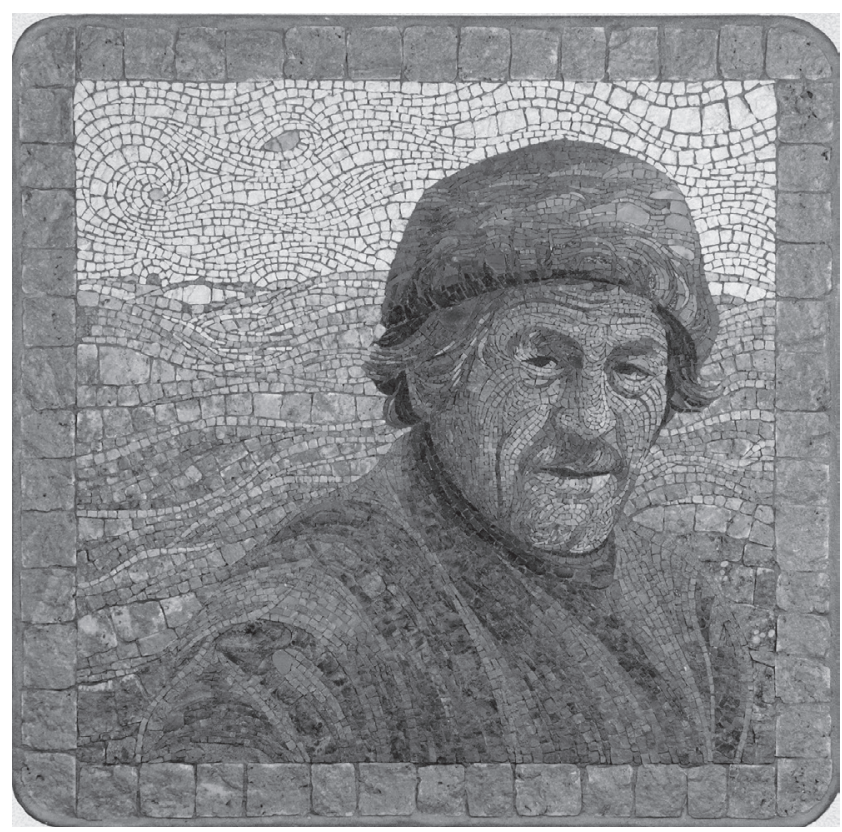

Снежана Јовчић Олђа, Тибор, 49 х 49 цм, 2011. 